\title{
Natural disasters as a development opportunity: a spatial economic resilience interpretation
}

\author{
Alexandru Bănică ${ }^{1,2} \cdot K$ Karima Kourtit ${ }^{1,3,4,5,6,7}$ (D) $\cdot$ Peter Nijkamp $^{1,3,4,7}$
}

Accepted: 13 July 2020 / Published online: 18 August 2020

(C) The Author(s) 2020

\begin{abstract}
Natural disasters are usually regarded as damage factors causing high private and social costs. Notwithstanding the incontestable validity of this premise, natural disasters do not necessarily lead to a structural deprivation of the area affected. Recent studies have clearly shown that in the long run one may even observe positive socio-economic effects ('blessings in disguise').

This paper investigates this challenging proposition by developing a risk-disasteropportunity framework for a territorial system, and by analysing the socio-economic impacts of natural shocks from a resilience perspective. This is inter alia done by designing a typology of natural disasters, and by presenting a systematic classification of long-range impacts.

An empirical test of the above proposition of positive recovery effects of natural disasters is carried out by using, in particular, long-term data from the worldwide EM-DAT database. The attention is then focussed on positive feedback loops in spatial systems that are affected by a natural perturbation. Various case studies (USA, China, Haiti, Chile, Japan) are undertaken in order to test the existence of long-term 'blessings in disguise' effects, using in particular the HDI-index. In
\end{abstract}

K. Kourtit

k_kourtit@hotmail.com

1 Alexandru Ioan Cuza University, Iasi, Romania

2 Romanian Academy, Iasi Branch, Romania

3 Open University (OU), Heerlen, The Netherlands

4 Polytecnic University, Ben Guerir, Morocco

5 Uppsala University, Uppsala, Sweden

6 Centre for the Future of Places (CFP), KTH Royal Institute of Technology, Stockholm, Sweden

7 Adam Mickiewicz University, Poznan, Poland 
various cases, such positive effects appear to exist, depending on the effectiveness of public management of natural disaster phenomena.

Keywords Natural disasters · Resilience $\cdot$ Blessing in disguise $\cdot$ Risk-disasteropportunity framework $\cdot$ Recovery effects

\section{Background}

This study presents a review and an examination of natural induced shocks and their economic impacts by using a holistic resilience-based approach that highlights the importance of perturbations in the evolution and development of territorial systems (e.g., cities or regions).

We live in a 'risk society' (Beck 1992) where threats multiply, as we face more types of hazards - not only just the 'usual' natural risks, but also an increasing number of human-induced natural perturbations. More people and assets are exposed to risk, as population grows and settlements expand, whereas social and technological improvements do not succeed in reducing the vulnerabilities of countries, regions or cities. This phenomenon is sometimes referred to as the 'geography of disruption' (see e.g. Yigitcanlar and Inkinen 2019).

The existing literature differentiates between shocks as phenomena determined by short-term deviations from long-term trends and stressors referring to variables reflecting long-run pressures co-determined by the shock resistance or vulnerability of system components (Bujones et al. 2013; Zseleczky and Yosef 2014). Shocks may transform into disasters which are serious disruptions of the functioning of a community or society at any scale (neighbourhood, city, region, country), causing significant human, material, economic or environmental losses which affect or exceed the ability of society to cope with, by using solely its own resources (UN 2016). Such disasters appear at the intersection of hazardous events (that may become shocks), exposure and vulnerability, but they are also highly influenced by lack of capacity to resist and reduce the consequence of these events. In this context, vulnerability and resilience are actually viewed as antonyms; it is the capacity of "bouncing back" that differentiates them. Still, reducing the resilience concept to returning to a stable state limits its understanding (Manyena et al. 2011). The present approach, concentrated mainly on the outcomes of a natural disaster in the short and long run, takes resilience as a keyword to highlight, from a territorial perspective, not only the differentiated capacity to diminish and manage losses, but also the growth and development opportunities that arise after a disastrous event.

One should make a distinction between resilience capacity and performance, as these are two different sides of the concept. The resilience capacity of a territory-e.g. a small rural area, a city, a region, or a country-relates, to a great extent, to the ability to anticipate not only the recurrent major natural disasters, but also the tipping points embedded in the system's characteristics and functionality that could sometimes generate more persistent and destructive crises. Resilience performance is complementary to the resilience capacity, as it looks at the outcomes by evaluat- 
RISK

Hazards
Exposure
Vulnerability
Adaptivity
RESILIENCE
CAPACITY

EVENTS/DISASTERS

OPPORTUNITIES

Fig. 1 A general framework of risks and disasters as opportunities for territorial systems

ing the response to past risk events or threats when compared with a reference state (Bristow and Healy 2017).

Therefore, assessing disasters integrates two different phases of, and perspectives on, shocks. The first is the ante-factum possibility and probability of a shock, which implies a potential destructive event (hazard), a vulnerable society/community, its exposure to the event and the (lack of) capacity to adapt and cope with the risk. The second implies the post-factum analysis of the shock, the direct and indirect impact and the spatially differentiated response of the economic and social system. In this phase the system might capitalise on the opportunities that are opened for economic growth, transformation, and development (see Fig. 1).

Seen from either perspective-as an (anticipated) capacity or as a (demonstrated) performance of a system-resilience highlights the potential of perturbations to create opportunities for structural changes, for innovation, and for transformation (Folke 2006). Resilience in the event of natural disasters means to learn to survive future events with a minimum loss of lives and assets; to enforce the sense of belonging to a place among residents; but also to (re)build a stronger and more diverse economy (Vale and Campanella 2005, Sawada and Takasaki 2017).

Consequently, a discussion about (natural) disasters is also about the opportunities that they open up in terms of the recombination of evolved structures and processes, the renewal of the territorial system, and the emergence of new trajectories. Resilience provides an adaptive capacity that might induce continuous development, as a dynamic adaptive interplay between sustaining and developing with change (Adger 2006; Smit and Wandel 2006).

There are two different approaches to resilience: "passive resilience" focuses on recovery and reconstruction and is usually limited to an emergency and disaster man- 
agement; and "transformational resilience" addresses in a comprehensive manner the underlying risks and vulnerabilities and can become a valuable decision-making tool for economic growth and sustainable development (Sudmeier-Rieux 2014).

From a resilience perspective, there is a need to contextualise natural catastrophes and the actions of society in the face of these shocks. This can be done by pursuing integrated assessments of both drivers that contribute to the emergence of the disastrous consequences and outcomes that cannot be always predicted nor can be removed, but can be perceived or transformed into beneficial events with the right (systemic) perspective and with properly cross-scale designed decisions and planning actions.

Acknowledging these ideas, this study tries to systematise existing studies and references on this research direction, and to highlight and analyse examples of different outcomes and attitudes emerging from different shocks that have occurred at various spatial levels.

The approach is focused on a spatial-economic perspective, as natural disasters have simultaneously geographical and economic implications, while the choice of spatial aggregation level influences both spatial relations in times of turbulences and the interpretability of economic indicators (Rusche 2010). It is a merger between space and economy; the spatial economy evaluates the interaction between systems of production, distribution or consumption in a spatial context, including managing and forecasting spatial development (Nijkamp and Ratajczak 2013); in our case, under the special conditions created by catastrophic natural events. Spatial-economic resilience is a multifaceted concept related and adapted to the specific shocks, specific contexts, aims, and spatial levels where the disaster occurs (Modica and Reggiani 2014, Koks and Thissen 2016). Therefore, our literature review is also combined with empirical findings from a descriptive statistical analysis of the available data in order to ground the assumptions and implications from a resiliencethinking perspective in long-term disaster management.

It is important to assess what are the real losses from the manifestation of different hazards, and to what extent the positive effects are known and differentiated by each type of shock and territory that is affected (low income/high income countries), the political and economic context, etc. Using available international databases (EMDAT, FRED Economic Data, etc.), statistical analyses and graphical illustrations can provide a more in-depth understanding of complex situations when the outcomes are less comprehensible; e.g., when discussing the relationship between multiple shocks/stressors and the consequent interrelated disasters.

When employing data to analyse losses emerging during and after a natural shock, one should keep in mind some limits:

- not every shock is represented in loss estimation;

- losses are often not comparable over time;

- not all losses are counted or can be counted;

- not all types of losses are included;

- losses are usually not comparable across geographical units;

- losses may differ depending on the database that is used (Gall et al. 2009). 
In order to articulate the theoretical framework for examining natural disasters and their differentiated outcomes, five case studies were selected. They share the following features: they are all well-known natural catastrophic events; their occurrences are not very distant in time; these events affected many people; and they induced major economic damages. Their significant impact was however, not the only criterion for their selection: they also exhibit five different approaches in disaster and post-disaster management, and therefore, also a different resilience capacity and performance. In particular, the five countries involved (China, USA, Japan, Chile and Haiti) represent five nations that have rather dissimilar economic capacities, institutional systems, social knowledge skills and risk prevention infrastructures that influence their ability to cope with — and capitalize on- the opportunities offered by the recovery process.

Up-to-date data on these important disasters and time series on economic indicators (before and after the shock) will be analysed in order to test and highlight the various scenarios and to explain the adaptive/transformative potential and final outcomes of these events.

\section{A systems approach to natural shocks and their territorially distributed economic outcomes}

\subsection{Shocks in systems dynamics from a resilience perspective}

Systems in general-and spatial systems in particular-are formed by a diversity of interacting elements that are hierarchically organised in structures that are complex, interactive and integrated. The multiple feedback loops and the continuous flows of matter, energy and information are not smooth processes. Actually, in the functionality of systems one may observe phases of continuity and accumulation, but also moments when thresholds are exceeded, when all elements, structures and mechanisms are challenged, and when disruptions occur. Nevertheless, these phases are highly important from a systems perspective, as they do not necessarily imply only multiple drawbacks and destructions, but they also make the system evolve, by adapting and transforming it into more complex and more developed forms. Therefore, systems thinking, lies at the core of resilience thinking as resilience is an emerging property of systems that are subjected to pressure or face adversity.

Resilience does not imply stability or (only) resistance. On the contrary, it means "possibility to change", while the other two concepts highlight the "impossibility to change" (Reggiani et al. 2002). A well-known principle in systems theory states that quantitative change beyond a critical point results in qualitative change (change of phase, modified state of the system), which means a new set of relationships among the elements of the system (Gharajedaghi 2006). Likewise, catastrophe theory states that on the inflection points or the threshold, systems may display catastrophic behaviour which makes them transform radically, and sometimes this means performing better than it would have been possible before (Zeeman 1976). Similarly, chaos theory states that seemingly insignificant or unexpected factors can have a huge effect on the overall outcome. Therefore, the focus when managing 
a system that might be confronted with multiple shocks should not be put on the hazard prediction itself but rather on ensuring a higher resilience capacity, i.e. maintaining functionality in different and sometimes critical conditions. The resilience of a system depends on a large number of drivers and feedbacks, but the actual controlling variables, which can maintain or return a system to an equilibrium state, operate at slow rates and are not so numerous (Walker et al. 2012). The catastrophes emerge usually as non-linear external pressures that can induce a regime shift, i.e. a switch in the dominant feedbacks, making the system reorganise into a different structure and function (Biggs et al. 2018).

There is a general agreement that disasters may undo many years of physical and human capital accumulation (Shabnam 2014). Meanwhile, most of the disasters are products of natural processes in the geophysical world and in human society, and are often required to maintain (anthropo)geosystem functions (Noy and Yonson 2018) by releasing trapped elements and permitting novelty to (re)shape the whole. Accepting this 'normality' from a systems perspective is the first step in recognising the importance of not just reducing direct and indirect losses, but also having resilient forms of governance at every territorial level.

In a systemic approach, the reality of resilience to (environmental) shocks is usually seen anthropocentrically, namely as the capacity to enable physical (infra)structures and the economy to withstand natural (and human-induced) disasters and to recover from them (WBG 2017). It can be also seen eco-centrically, as the capacity to quickly return critical environmental and ecological services to functionality after a disaster, while applying the learning process to reduce vulnerabilities to, and risks of, future incidents (EPA 2015).

A systems approach to extreme natural events is highly complex, as variables from different domains interact at multiple scales. Resilience is a systemic reaction to shocks and disturbances that can be shaped from resistance to change, to small incremental adaptation measures, and to a radical transformation of the system structure.

In order to be sustainable, traditional systems practices have always been oriented towards anticipating and resisting disruptions, but they might remain vulnerable to unforeseen factors. Therefore, the inherent resilience of a system should be taken into account based on factors such as diversity, efficiency, adaptability and cohesion (Fiksel 2003). This would integrate learning processes and self-organization skills, innovation and polycentricism, resourcefulness and redundancy for a better adaptation to continual change and to the reality of always-recurring and equilibriumdriving major "energy releases" of nature and society.

For example, a higher diversity provides multiple alternatives for action during a disturbance, while redundancy ensures that one element of the system could be replaced by another in case it does not function (Biggs et al. 2012). Connectivity makes possible the exchange of materials, energy and information which are necessary for a system to function. In addition, flexibility - the capacity to learn and adapt and the willingness to make the necessary transformation when the opportunity arises-is highly important to cope with uncertainty (de Bruijn et al. 2017). 
The outcomes of transformation that can be triggered by natural shocks (or other types of perturbation) were recently discussed by Thomalla et al. (2018), and consist of:

- recombination pre-existing elements, components, functions or feedbacks in territorial systems, typically triggered by, for example, extreme climate events;

- transformative adaptation, when transformation takes place at larger scales or at a higher intensity. The system is forced to accept a new context, new elements, or the relocation of former elements;

- incremental adaptation, triggered by major disasters, when the system makes qualitative changes of structure and function, and establishes new goals, perspectives and governance regimes.

After this concise overview of concepts of dynamic and resilient systems, we will in the next subsection offer a typology of natural disasters.

\subsection{Typology of natural disasters and their differentiated impacts}

Most of the existing classifications divide natural shocks into five categories: (a) geophysical disasters (e.g. earthquakes, tsunamis, volcanic eruptions); (b) hydrological disasters (e.g. floods); (c) meteorological disasters (e.g. storms, hurricane, and tornadoes); (d) climatological disasters (extreme temperature, droughts, and consequent wildfires); (e) biological (epidemics, pandemics). Worldwide, on average, there are 50 disasters of a significant size annually. The hydrological disasters are the most common, while the geophysical disasters count for less than $10 \%$ of the total number of major natural disasters (Klomp 2016). Nevertheless the meteorological disasters produce the highest amount of economic damage, while the geophysical disasters produce the most human losses.

One can make a clear distinction between these categories of disasters, not just in terms of frequency, predictability and preparation possibilities (hydrological and climatic, which are more predictable and easier to tackle, when compared with geophysical and meteorological disasters), but also in terms of the duration (geophysical disasters are the shortest, followed by meteorological, while hydrological and climatic hazards can take weeks to months) and the geographical coverage of damage, from local (geophysical, meteorological) to regional (hydrological and climatic) (Klomp 2016).

Fig. 2 illustrates which natural disasters have been the most frequent on each continent from 1970 to 2019. Asia is, by far, the most natural disaster-prone continent in terms of total number of victims, as it is also the most populated. Meanwhile, Africa has the most numerous deaths in climatological disasters, while in Europe meteorological disasters are the most common. In terms of economic losses, in the last 50 years, America registered similar losses to Asia, but the hierarchy of disasters in terms of direct economic impact is dominated by meteorological events in the case of America, while Asia is more affected by earthquakes and floods.

Figs. 3 and 4 show the distribution of the major disastrous events over Europe in the last 30 years and the consequent losses. One can observe the predominance of natural disasters that also have the most powerful impact both in terms of lives 
Fig. 2 Losses in each continent caused by each main type of natural disaster (1970-2019). a No. of deaths; b economic losses ('000 \$) (Source: EM-DAT: The Emergency Events Database-Université Catholique de Louvain (UCL)-CRED, D. GuhaSapir-www.emdat.be, Brussels, Belgium, 10.10.2019)
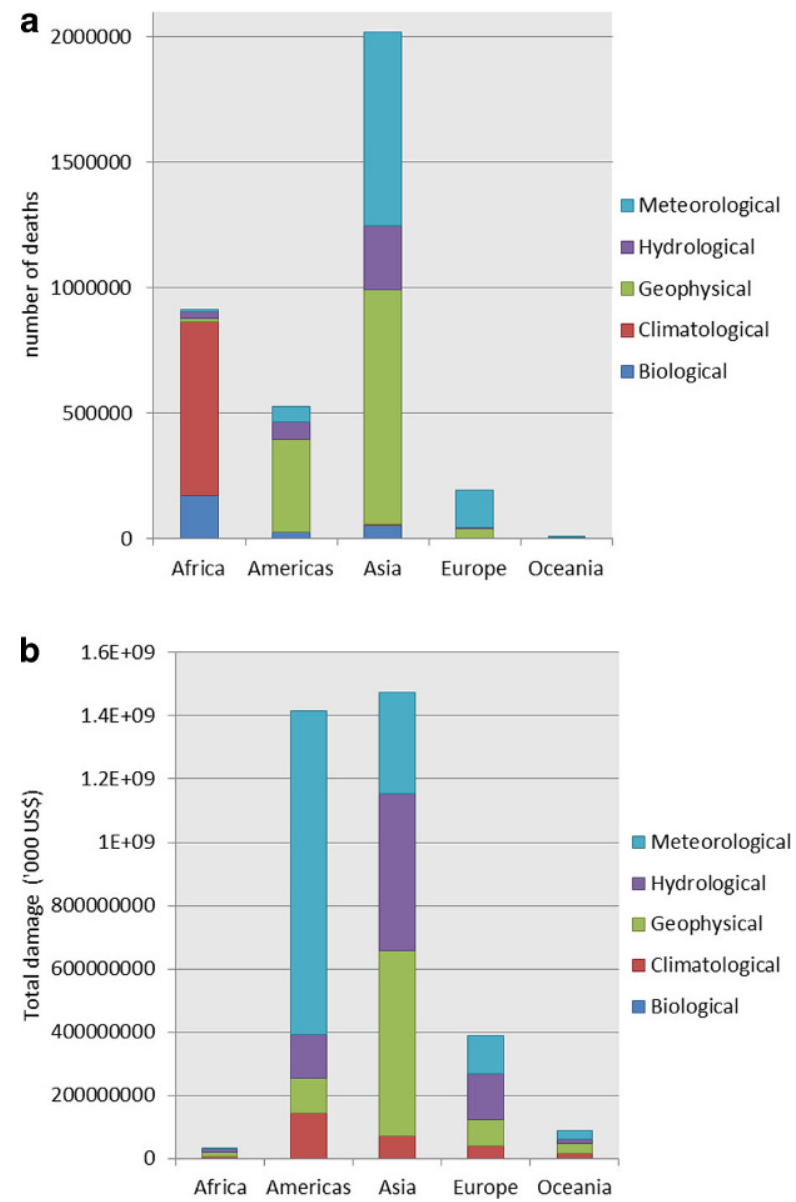

lost and affected population, but also when assessing the material damage. Their occurrence is unequal, as there are periods with a high concentration of overlapping high-intensity disasters (1994-1995, 2000-2003, 2006-2007, 2012-2015, etc.), alternating with periods of relative calm (1993-1993, 2006-2008, 2004-2005, etc.).

When quantifying losses by each subtype, the differences are obvious: floods are the most frequent disaster. They affect the most Europeans and produce most of the economic damage both in the Eastern and Western parts of that continent. However, the deadliest events are extreme temperatures and especially heat waves. Storms also affect a large share of the population and regularly produce economic damage, while droughts also extend over large areas and have an impact on both agriculture and the well-being of the population. The destructive earthquakes are less frequent, and produce less causalities, but still induce considerable material losses.

The impact of disasters seems to be growing if one looks at the non-normalised total economic losses. However, if normalising data by using GDP and the inflation 

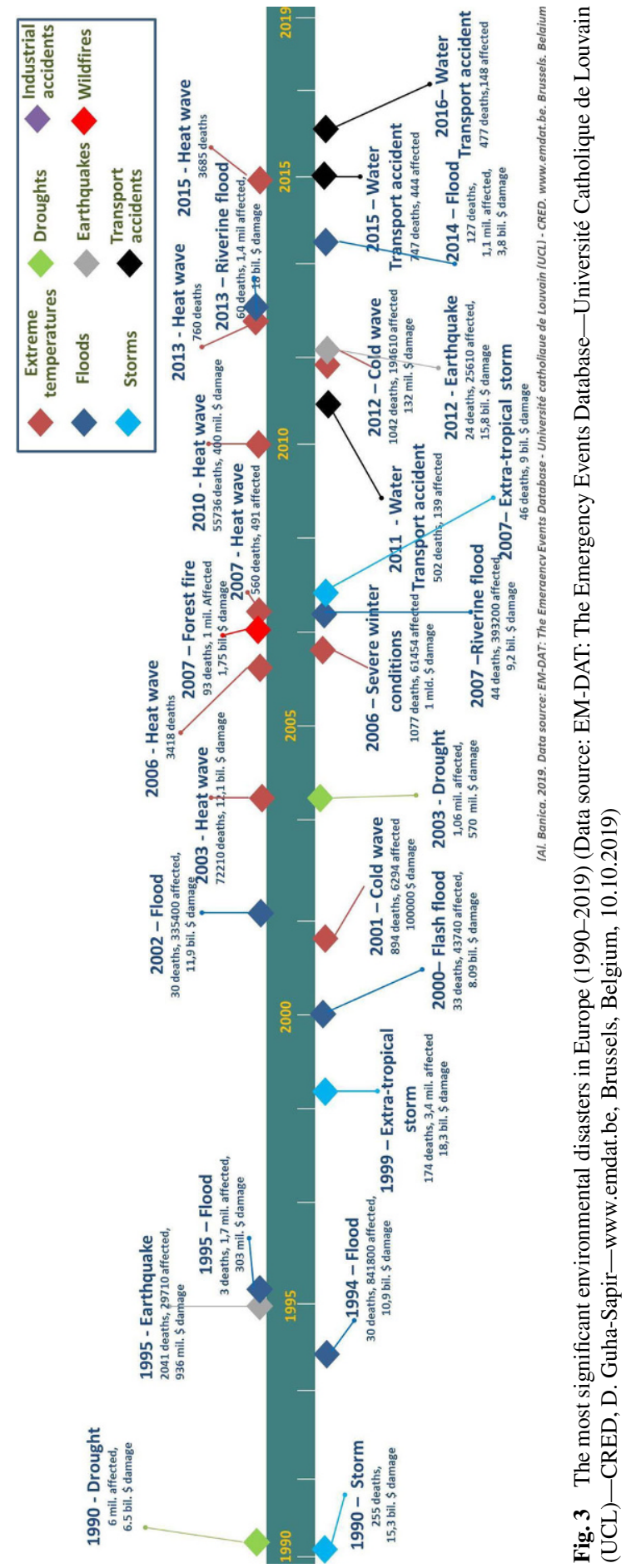
A. Bănică et al.

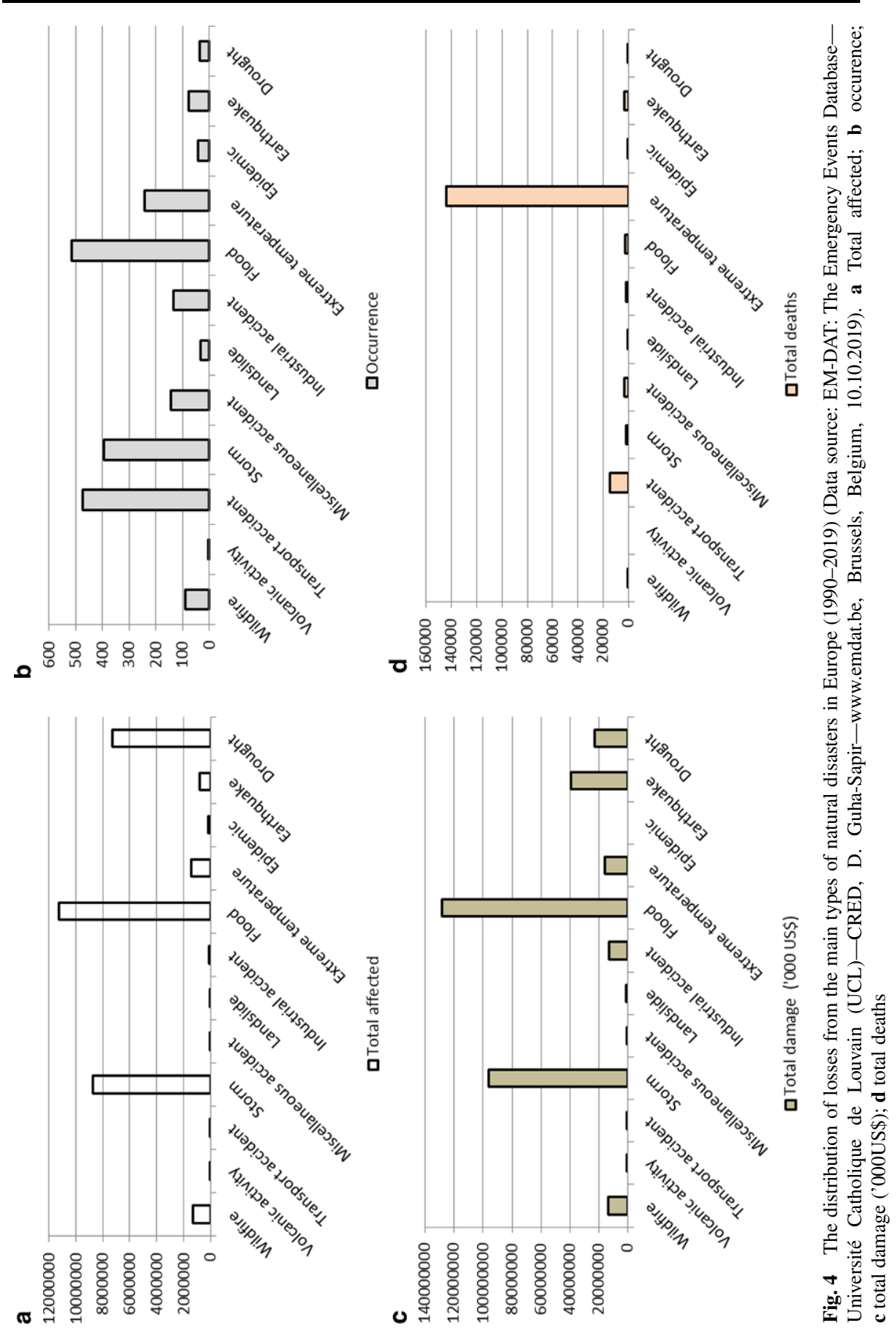


rate at the global scale, there is no significant global trend through time (Neumayer and Barthel 2011).

\section{Spatial resilience to natural shocks in relation to economic growth}

The disasters' effects are determined by pre-impact conditions (exposure, physical and social vulnerability), hazard magnitude and intensity as well as by post-impact conditions (response and recovery) (Lindell 2013). Short-term destruction and longterm economic losses and gains are numerous, interlinked and complex and might affect a certain area, absorbing significant financial resources from different socioeconomic sectors (Modica and Zoboli 2016).

Limiting the effects of natural disasters is highly important. In fact, disasters are likely to be more localised over time, as countries develop and become less vulnerable to similar natural events and have better knowledge and capacity to tackle these major perturbations. At regional scale, the ability to withstand exogenous shocks influences not only short-term prosperity, but also long-term development (Pudelko et al. 2018). At city level the lack of spatial resilience can be demonstrated if, on the long run, the urban area does not have the ability to return to a similar state to the original situation, as reconstruction is delayed while people are dissatisfied (see the case of L'Aquila illustrated by Contreras et al. 2016). Cutter and Derakhshan argue that all disasters are, in fact, local, as there are differences in exposure and vulnerability at community level that also imply a certain variance within the affected region. They conclude that, although measures can come also from national level, it is the task of communities to articulate and implement resilience goals and to measure the outcomes (Cutter and Derakhshan 2018).

Meanwhile, building resilience on a certain scale can also contribute to the increasing resilience to other spatial levels i.e. positive cross-scale relation (as it is the case of a resilient city that might diffuse resilience to regional level). Yet the contrary phenomena could also occur as a higher resilience capacity at one level can be in the detriment of another level (Béné 2018). In this respect it is important to determine the key threats to address and the suitable scale to tackle problems and to implement proper territorial planning solutions (Allen et al. 2016).

One could refer to the localisation of a disaster in terms of either its geographical or economic impact (Table. 1). Most of the disasters are geographically localized with localised economic effects (most of the small-scale disasters), but there are also localised disasters that can induce widespread effects (e.g. the 2010 earthquake from Haiti). Conversely, there are widespread catastrophes that have had localised economic effects (the 2018 drought in Uruguay, the 2016 hurricane in Ecuador),

Table 1 The issue of disasters' localisation (after Albala-Bertrand 2007)

\begin{tabular}{llll}
\hline & & $\begin{array}{l}\text { Economic viewpoint } \\
\text { Localised }\end{array}$ & Widespread \\
\hline $\begin{array}{l}\text { Geographical } \\
\text { viewpoint }\end{array}$ & Localised & MOST DISASTERS & SOME DISASTERS \\
& Widespread & DIVERSIFIED ECONOMY & UNDIVERSIFIED ECONOMY \\
\hline
\end{tabular}


while an extreme case arises when disasters are widespread both geographically and economically, this happening usually in the developing agricultural undiversified economies (e.g. the 2012 drought in Sahel) (Albala-Bertrand 2007).

At the same time, the assessment of the impact of natural disasters depends on the perspective and data. Given the increase in GDP and wealth per capita, there are authors arguing that there is no growth in economic losses due to natural disasters if normalised values are taken into account (Neumayer and Barthel 2011). Meanwhile, in absolute values, one can see an exponential growth of the losses from natural disasters. However, even if natural disasters are more frequent and more intense, society has found ways to mitigate losses and to induce economic growth and eventbeneficial transformations/development after disastrous events.

In this regard, there are certain long-term scenarios that have been envisaged and need to be tested at macroeconomic level (Fig. 5). One can associate the following scenarios with different types of disasters, in the countries/territories that were affected (Klomp 2016):

- Scenario $A$-a return to the initial balanced growth path as capital is restored-in the case of climatic disasters in least developed and also in developed countries;

- Scenario $B$-replacement investments are ultimately affected by capital depreciation, while the initial capital-labour ratio is restored, and GDP is returning to the original balanced growth path-in case of geophysical and hydro-meteorological disasters in both least developed and developed countries;

a

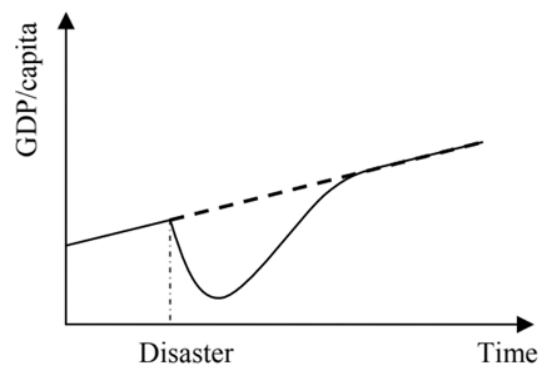

C

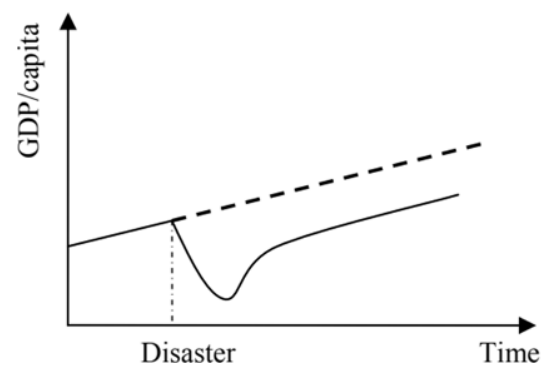

\section{b}

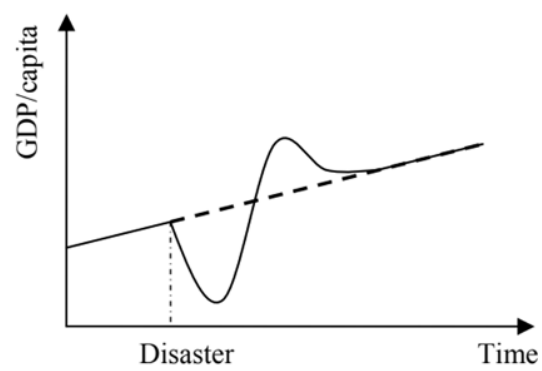

d

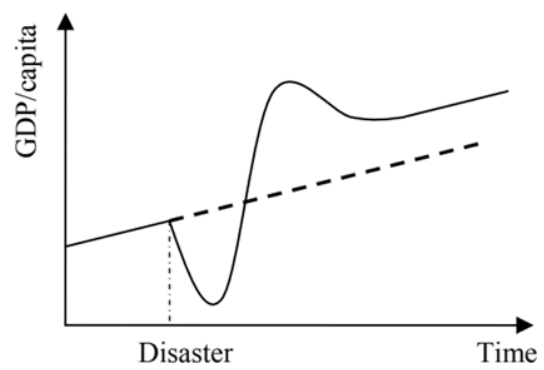

Fig. 5 Possible long-run Impact of a disaster on GDP per capita (Chhibber and Laajaj 2008, 2011). a Scenario A; Scenario B; c Scenario C; d Scenario D 
- Scenario $C$-a balanced growth path, as the private sector is not able to invest in recovery expenses - in the case of geophysical and hydro-meteorological disasters mostly in least developed countries;

- Scenario $D$ - a faster balanced growth path by increasing the technology level-in the case of geophysical and hydro-meteorological disasters mostly in developed countries.

These four scenarios can be considered at different geographical scales (global, continental, national, regional) in relationship to specific natural shocks in order to study the relation between the impact/intensity of the disaster and the resilience response.

In addition, Hallegatte (2014) identifies a 'bifurcation', i.e. two differentiated scenarios derived from natural disasters: 1) if they are small enough, they represent short-term events that are rapidly tackled by the reconstruction capacity of society and do not affect long-term income and growth. In terms of resilience theory, it is resistant: 2) if they are too large in terms of frequency or intensity compared with the reconstruction capacity, they have a significant impact on income, economic growth and development (negative, positive or both). It is the recovery phase of resilience through adaptation and transformation.

The aim of impairing resilience to disasters is not just to maintain GDP growth, which has a limitation as proxy, but in particular general economic development and social welfare. This requires evaluating, before and after the shock, not just the GDP value, but other individual or integrated indicators that are more comprehensive from a development perspective. There are indeed economic analyses of the natural shocks impact that take into consideration each sector of economic activity and each type of disaster (Loayza et al. 2009).

According to Noy (2009), the potential factors which influence the costs of catastrophes include also differences in population size, the size of the economy and the timing of the shock, while the macroeconomic impact is much greater in developing

Fig. 6 Positive feedback loop-poverty trap of natural disasters (Hallegatte 2014; modified)

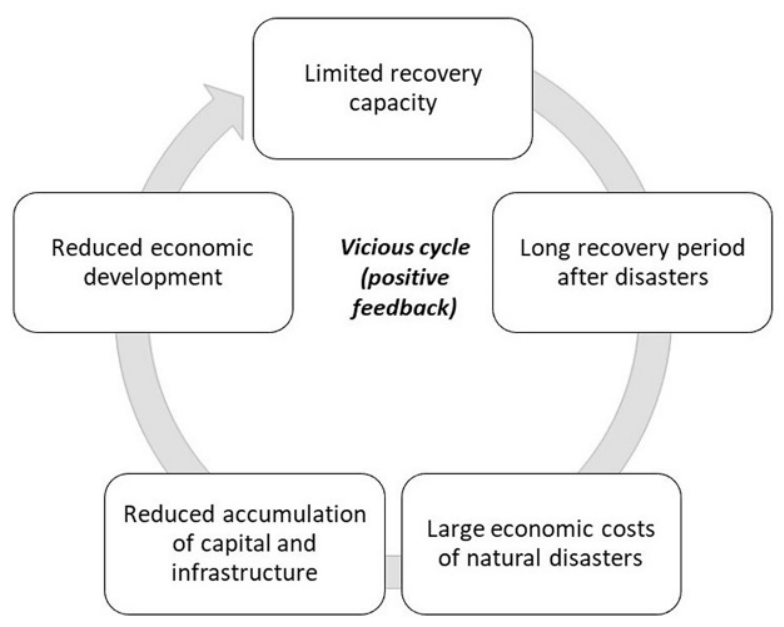


countries than in developed economies. Actually, developing countries are trapped in a vicious cycle of high vulnerability to shocks, larger economic costs (relative to their GDP) and a longer recovery period, comprising a more reduced and slower capital accumulation and economic development that will further reduce the capacity to tackle future disasters (Fig. 6). Therefore, disasters may contribute to increasing the gap between developed and developing countries, between the poor and the rich regions, cities, communities and individuals, increasing both spatial disparities and social inequalities.

Generally, it is expected that higher income, higher educational attainment, higher institutional performance, more openness and solid financial systems and other economic development indicators correlate with fewer disaster losses (Toya and Skidmore 2007; Noy 2009; Padli et al. 2018). In conclusion, disaster impact assessment is a new emerging field that deserves full-scale attention from both a policy and research perspective.

\section{The importance of place-specific resilience in transforming shocks and losses into opportunities.}

The outcome of natural disasters might be not just short-and long-term losses and downturns, but also a Schumpeterian creative destruction, including direct and indirect benefits during the recovery phase, even economic growth, structural transformation/modernisation of functional structures and development. In this view, disasters could become "blessings in disguise" (Borsekova and Nijkamp 2019), chances for the system to evolve in the face of chaos and to improve while transforming with the shocks, not just to resist their effects (Likens et al. 2009). In this way, disasters open up opportunities for the territories and communities to rebuild and improve outcomes, i.e. to be antifragile (Taleb 2012). Nevertheless, not all previous models used in disaster economics are compatible with these ideas.

Neoclassical growth models do not consider that natural disaster will affect the rate of technological progress; they are only able to boost short-run economic growth, while the general impact is negative on the economy as a whole. In this context, input-output (i-o) and computable general equilibrium (CGE) models play often a role in disaster impact studies.

In contrast, endogenous growth models acknowledge that catastrophes might become engines of economic growth, being catalysts for reinvestments and higher productivity of capital stock (Shabnam 2014).

The approaches based on social accounting matrices make use of prediction of input-out (I-O) models and computable general equilibrium models (CGE) in order to identify all monetary flows between economic sectors. Such models take normally for granted that natural disasters have a negative impact on the overall economy (Crespo-Cuaresma 2010; Botzen et al. 2019).

More spatially-oriented catastrophes models use GIS to estimate the direct impact from natural disasters at different geographical scales, by accounting for losses in the exposed areas with various intensities and estimating the probabilities of their future occurrence and expected damage. Finally, regional-economic models have emerged, 
often as a critique to the previous ones (except for the catastrophe models), which were rather 'spatially blind'. Therefore, such models take geography explicitly into account, in order to connect the macro-level indirect impact (e.g. output losses) to the micro-level of directly destroyed capital stock (Botzen et al. 2019).

Various analysis framework postulate that natural disasters are opportunities to upgrade productive capital, to improve technology and, finally, to develop. The explanation is based on the fact that older facilities and utilities are more prone to be damaged during a natural disaster. Therefore, their replacement with newer assets (and not necessarily the technological progress) may have a positive impact by inducing a growth post-disaster path (Okuyama et al. 2004). Evaluating losses and the necessary resilience capacities are highly scale-dependent. Albala-Bertrand (1993) argues that 'local cannot be equated to national, neither can human tragedy be equated to economic setback, nor can recovery be equated to only financial, or international aid'.

This impact depends on the capacity of the territorial system to capitalise on the "window of opportunity" which means the moment when the issues become so urgent that it is necessary to push the change rapidly. The urgency is based, on the one hand, on the need for residents to come back to their houses and lives and for business owners to restart their activities, and, on the other hand, by the short-term attention given to the affected territory (at the national and international scale) and the consequent inflow of capital for reconstruction. In times of crisis after a natural disaster it is thus a great advantage to have a good plan in place not only for shortrange emergency and rehabilitation actions but also for long-term reconstruction and redevelopment measures (Berke and Campanella 2006). It is about developing and having a vision after a disaster, which provides a direction-setting framework and, most of all, to "inject long-term resiliency into short-term recovery" and to have a broader picture of community resilience integrated in regional and national disaster response and reconstruction policies (ibid.).

Disasters have demonstrated that the recovery, rehabilitation and reconstruction phase, which needs to be prepared ahead of a disaster, is a critical opportunity to "Build Back Better", including through integrating disaster risk reduction into development measures, thus making nations and communities resilient to disasters (UNISDR 2015, p. 21).

The opportunities created by disasters can be studied from multiple perspectives and the current literature provides insightful studies, inn multiple directions, on the relationship between aid and growth (Doucouliagos and Paldam 2007), and also on the relationship between natural disasters and income inequalities (Yamamura 2013). A great interest can also be observed in the link between natural disasters and capital accumulation (McDermott 2012), and also in disaster risk reduction by innovation (Izumi et al. 2019) and/or by adopting and embodying new technologies that will improve productive capital (production plants, residential areas, infrastructure) (Hallegatte 2014). As consequence, capital losses can be compensated for by higher productivity, more safe and environmentally friendly assets and consequent welfare benefits (ibid). The resilience to natural disasters highly depends on the quality of institutions (Kahn 2005). The relationship between the degree of foreign technology absorption and catastrophic events (Skidmore and Toya 2002; 
Table 2 Selected case studies of natural disasters

\begin{tabular}{|c|c|c|c|c|c|c|c|}
\hline Year & Country & $\begin{array}{l}\text { Type of } \\
\text { disaster }\end{array}$ & $\begin{array}{l}\text { Scale of im- } \\
\text { pacted areas }\end{array}$ & $\begin{array}{l}\text { Total } \\
\text { affected }\end{array}$ & $\begin{array}{l}\text { Total } \\
\text { deaths }\end{array}$ & Injured & $\begin{array}{l}\text { Total } \\
\text { damage } \\
\text { ('000 US\$) }\end{array}$ \\
\hline 2005 & USA & $\begin{array}{l}\text { Meteorological } \\
\text { (Hurricane) }\end{array}$ & $\begin{array}{l}\text { Urban (New } \\
\text { Orleans) and } \\
\text { sub-national } \\
\text { scale (Louisiana) }\end{array}$ & 830,336 & 1915 & 39 & $158,230,000$ \\
\hline 2008 & China & $\begin{array}{l}\text { Geophysical } \\
\text { (Earth- } \\
\text { quakes) }\end{array}$ & $\begin{array}{l}\text { Regional-Sichuan } \\
\text { Province }\end{array}$ & $47,369,797$ & 87564 & 368,412 & $85,492,000$ \\
\hline 2010 & Haiti & $\begin{array}{l}\text { Geophysical } \\
\text { (Earthquake) }\end{array}$ & $\begin{array}{l}\text { Departments } \\
\text { of West, } \\
\text { South-East, } \\
\text { and Nippes }\end{array}$ & $3,700,000$ & 222,570 & 300,000 & $8,000,000$ \\
\hline 2010 & Chile & $\begin{array}{l}\text { Geophysical } \\
\text { (Earthquake) }\end{array}$ & $\begin{array}{l}\text { Regions: Val- } \\
\text { paraíso, Santi- } \\
\text { ago, O'Higgins, } \\
\text { Maule, Biobio, } \\
\text { Araucanía }\end{array}$ & $2,671,556$ & 562 & 10,334 & $30,000,000$ \\
\hline 2011 & Japan & $\begin{array}{l}\text { Geophysical } \\
\text { (Earthquake, } \\
\text { tsunami) }\end{array}$ & $\begin{array}{l}\text { Tohoku Region } \\
\text { (Aomori, Iwate, } \\
\text { Miyagi, Akita, } \\
\text { Yamagata, } \\
\text { Fukushima) }\end{array}$ & 368,952 & 19,848 & 6065 & $210,000,000$ \\
\hline
\end{tabular}

Crespo-Cuaresma et al. 2008) is also analysed to highlight the positive effects on knowledge spillovers between developed and developing countries. This can also be linked to the impact of disasters on international trade (Gassebner et al. 2010). When analysing urban disasters, Borsekova et al. (2018) stress that, during recovery, updated infrastructure, together with external economies of densities, proximity and connectivity might reinforce the long-range development of a city.

As an empirical illustration of the above mentioned issues, five very well-known case studies are taken into account in order to explore different approaches to disaster management, at different geographical scales (Table 2).

Haiti, 2010 vs Chile, 2010 On 12 January 2010, a 7 degrees on the Richter scale earthquake devastated Haiti, the least developed country in the Northern hemisphere, causing 230,000 deaths, over 30,000 injuries, the replacement of 1.5 million people, and a considerable number of buildings damaged or collapsed. The poor building construction, the unprepared population, and the lack of, a proper emergency system were important factors of vulnerability. Haiti did not have the capacity to respond properly, but the international intervention and aid was unprecedented. The response was global, i.e. countrywide, although the disaster struck only the Western part of the country. The rehabilitation of key infrastructure, including the Cap Haitian to Labadie road, enhanced tourism potential and improved access to markets and services (WB 2019). Meanwhile, the planning process in Port-au-Prince and surrounding areas led to the reconstruction of 430,000 buildings, while the engineers and masons were trained in paraseismic construction. Nevertheless, the recovery and 


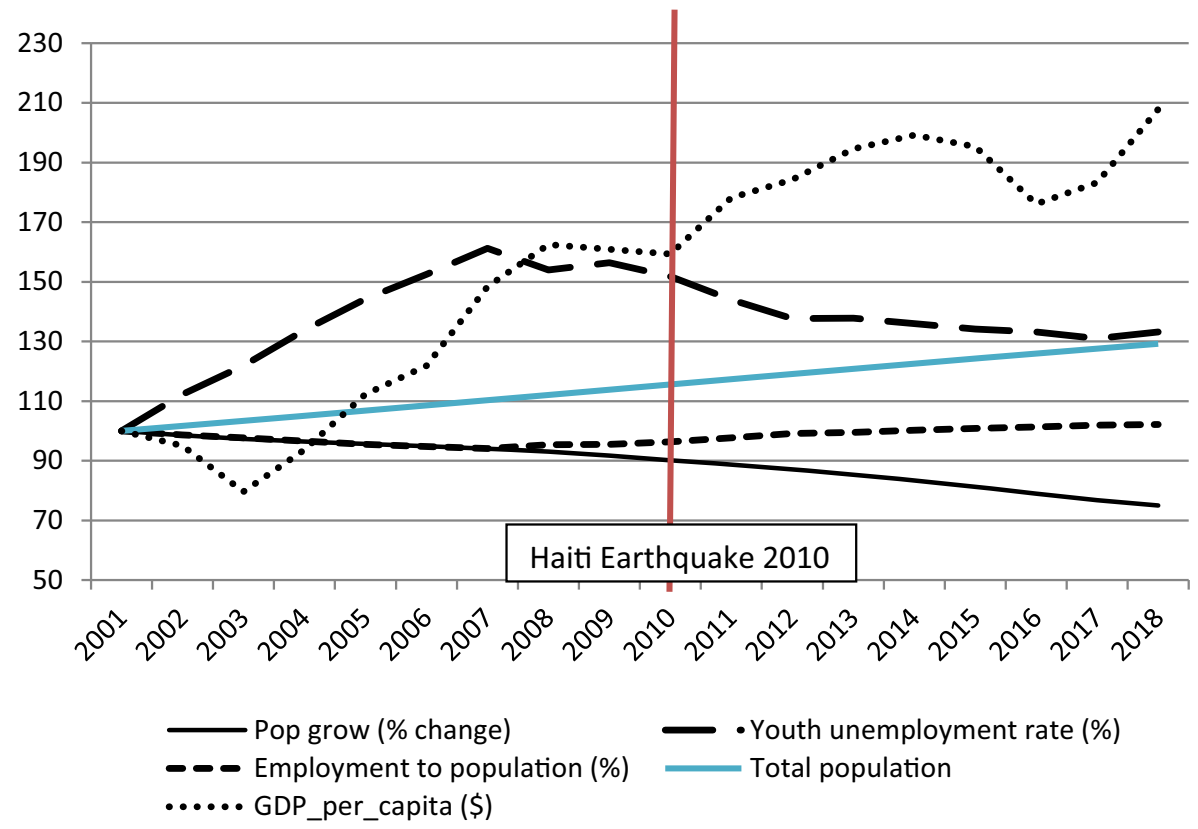

Fig. 7 Haiti-Social-economic indicators before and after the 2010 earthquake

reconstruction was marked by uncertainty, and is seen, by many authors, as a failure due to the severe democratic deficit, corruption, and bad management of funds. One can conclude that the emergency response based on current needs had a negative impact on the objectives of future development (Biquet 2013). Even now, investments in living conditions not just for the short run (as was the case in agriculture and education), but also for the long run-for access to medical care, housing, water etc.-are highly needed. The country experienced a short boost in terms of GDP/ capita that was not sustainable, but increasing share of unemployment, especially in the case of young population maintained long time after the disaster. Another interesting fact was the maintenance of positive dynamic of total population although the growth rate was highly diminished (Fig. 7).

After six weeks, on 27 February, 2010, the Maule disaster in Chile was, by that time, the sixth earthquake ever registered in terms of magnitude ( 8.8 degrees on the Richter scale), together with the following tsunami, killed around 500 people and affected 2 million inhabitants, damaging 260,000 houses, 4000 schools and 70\% of the hospitals in the exposed areas, causing losses of US\$30 billion (18\% of the GDP of Chile) (Siembieda et al. 2012). The response and recovery were much better planned than in the case of Haiti. The slogan of the Plan de Reconstruccion was our challenge: turn a catastrophe into an opportunity for better cities, better life (MINVU 2011) The challenge was to balance speed, deliberation and long term strategic vision (Plat and So 2016). First, critical infrastructure was reinstalled including electricity, water, gas and telecommunications (Moreno and Shaw 2016). 70,000 dwellings were rebuilt: not just ghettoes for the short-term, but reconstructing 
cities to mitigate exposure to future earthquakes and tsunamis. These dwellings were built rapidly: by October 2012, more than 50\% were already finished and occupied, but also in a more sustainable manner in terms of resistance, energy efficiency, and comfort. Coastal areas were managed differently than the inner zones, as the tsunami risk was also taken into account. Nevertheless, managing spatial issues had to be considered taken into account while deliberating whether to rebuild in the same location or move and had to be managed by taking into account the damage, the actual risk, the economic implications of moving, etc. National coordination was limited in defining the scale of the problem and in allocating resources, but instead the regional authorities and teams of experts were forced to coordinate the process (Platt 2019).

There were four principles that formed the basis of the overall approach: ensuring safety in the event of to natural shocks, sustainability (ensuring also ensuring high energy efficiency and sustainable transport systems), quality of life (of all stakeholders) and future development (providing conditions for economic development, new production and service activities according to the potential of each locality). The economic recovery process was based on rapidly restoring the critical infrastructure and building temporary accommodation to keep/reinstall businesses.

Hurricane Katrina, New Orleans, 2005 One of the greatest catastrophes suffered by an American city in the last century, the hurricane in New Orleans, was followed by a flood, killed 15,000 people, destroyed 182,000 homes and infrastructure in $80 \%$ of the city area. In economic terms, it was the most costly disaster in US history, and the second worldwide: $\$ 40-50$ billion including direct property losses (\$20-22 billion), still ongoing economic losses (\$4-8 billion), and emergency assistance ( $\$ 16-20$ billion).

The New Orleans disaster is characteristic of what is called the safe development paradox stating that increased safety induces increased development leading to increased losses (Burby 2006). Here it can be called the "levee effect" as the construction of levees had encouraged additional development that finally resulted in much greater damage when the levee was eventually overtopped.

The recovery was a process of infrastructure re-establishment, demolishing damaged houses, rebuilding and repopulating, but economic resilience was based more on private investment in housing and commercial redevelopment than on the state intervention. The GDP of New Orleans, LA, MSA fell less than 3\% before recovering two years later, but the following economic recession did far more damage. Meanwhile, there were significant shortcomings in the recovery process that involved well-intentioned, but short-sighted, public policy decisions at all levels of government (Burby 2006). First, the uneven urban regeneration resulted from a public housing sector that symbolises the federal government's failure to address the persistent problems of urban poverty (Scoppetta 2016). Many people left New Orleans never to return, and the disaster transformed the city. Although, after the disaster, the city now has better public housing, school system and public health, one can criticise the unjust reconstruction and development. One consequence is the changing ethnic structure: there is now more white population, as the share of AfroAmericans decreased from 67 to $23 \%$. 


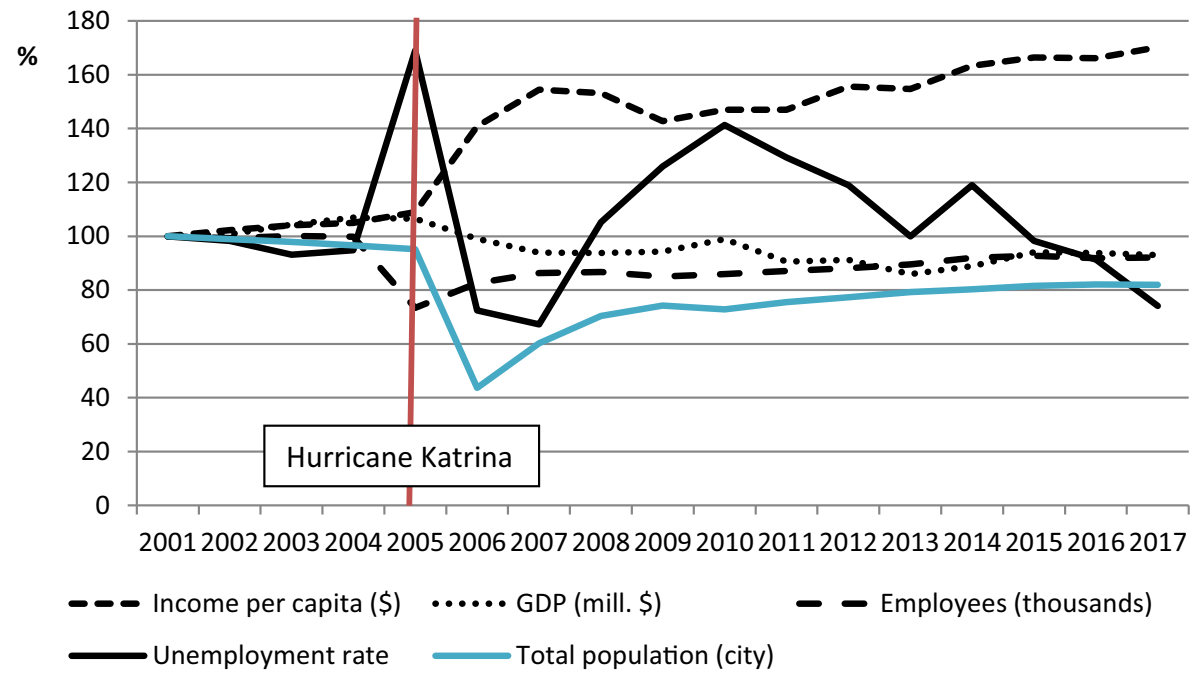

Fig. 8 Social-economic indicators before and after the 2005 Hurricane Katrina

In some ways, New Orleans has not yet recovered (total population, employment, households), but in other ways it has improved to higher levels compared with preKatrina figures (GDP, number of businesses, improvement of infrastructure) (Flowers 2018) (Fig. 8).

Tohoku Earthquake, Japan, 2011 Starting on 11 March 2011, the Tohoku earthquake, tsunami, and technological (nuclear power plant) accident was a 'black swan', an unprecedented triple disaster. The human damage from the 11 March earthquake and tsunami was reported to be 19,846 deaths, while 368,820 people were affected. Moreover, the consequent tsunami damaged the Fukushima Daiichi nuclear power plant with blasts occurring in four reactors when the cooling systems went offline, finally resulting in radioactive leaks. The physical damage caused by the geophysical disaster consisted of destroyed buildings, roads, bridges, embankments and levees. More than 130,000 residential buildings were demolished or damaged in 10 prefectures, while the total losses were 210 billon US\$ (only $18 \%$ were insured losses) which makes it the most expensive disaster of our times. The "levee effect" (the false sense of security given by engineered infrastructure), together with the "domino effect" (one hazard triggering another), resulted in a major NaTech disaster (Rehdanz et al. 2015).

The recovery process consisted of emergency response measures such as sheltering the evacuees, restoring the infrastructure and public services, and also reconstruction support for business by special loans and a Recovery Emergency Guarantee program that started in 2012. The disrupted linkages of supply chains were partially reinstalled, although the energy issue remained a difficult problem after the closing of nuclear capacities that created a long-term dependence on imported fossil fuels. Support was also provided to the farmers, as $40 \%$ of the agricultural businesses that 
Table 3 The 9 most frequent disaster subtypes in Japan (1970-2019) and the corresponding main losses (Data source: EM-DAT: The Emergency Events Database-Université Catholique de Louvain (UCL) - CRED, D. Guha-Sapir—www.emdat.be, Brussels, Belgium, 10.10.2019)

\begin{tabular}{llllll}
\hline Disaster type & $\begin{array}{l}\text { Disaster } \\
\text { subtype }\end{array}$ & $\begin{array}{l}\text { Events } \\
\text { count }\end{array}$ & $\begin{array}{l}\text { Total } \\
\text { deaths }\end{array}$ & $\begin{array}{l}\text { Total af- } \\
\text { fected }\end{array}$ & $\begin{array}{l}\text { Total damage } \\
\text { ('000 US\$) }\end{array}$ \\
\hline Storm & $\begin{array}{l}\text { Tropical } \\
\text { cyclone }\end{array}$ & 139 & 32,734 & $7,791,155$ & $75,262,100$ \\
Earthquake & $\begin{array}{l}\text { Ground } \\
\text { movement }\end{array}$ & 51 & 161,901 & $1,409,526$ & $171,443,400$ \\
Flood & Flood & 35 & 13,075 & $8,523,971$ & $9,768,300$ \\
Storm & Storm & 23 & 1802 & 192,814 & 453,500 \\
Landslide & Landslide & 19 & 927 & 650 & 248,000 \\
Storm & $\begin{array}{l}\text { Convective } \\
\text { storm }\end{array}$ & 17 & 280 & 122,385 & $6,672,200$ \\
Flood & Riverine & 16 & 290 & 199,024 & $5,316,000$ \\
Volcanic & flood & & & & \\
activity & Ash fall & 15 & 515 & 99,979 & 132,000 \\
Earthquake & Tsunami & 14 & 32,576 & 436,947 & $212,821,000$ \\
\hline
\end{tabular}

were affected by the tsunami restored their operations one year later, which was also the case in seafood processing activities (IRP 2013).

One of the criticisms addressed to the Japanese government after a big disaster like the Tohoku earthquake is that it does not consider the recovery process as opportunity to incorporate measures to foster innovation. Although support from communities and non-governmental agencies is implied in the recovery process, the entrepreneurs were supported, but not propelled, to make radical changes within the economic system. It was argued by different scholars that private investments in production and employment, together with public investments in infrastructure and peoples commitment in striving for a better livelihood could lead the Tohoku region onto a new development path (Hayashi 2012) (Table 3).

Sichuan Province Earthquake, China, 2008 The Great Sichuan Earthquake struck on 12 May 2008 in the Western part of China with a magnitude of 8.0 on the Richter scale, causing almost 70,000 deaths, 18,000 missing people, 375,000 injured people, 7.80 million collapsed houses, 24.6 million houses damaged, and total direct economic losses of 135 million USD. The severe impact attracted both national and international attention, while various non-governmental organisations and non-profit organisations had offered their support. However, the post-event intervention is an example of government-led, top-down reconstruction. The stateguided approach of response and recovery was first set by an Ordinance, and then by regional development plans for the reconstruction of Sichuan-a strategic geographical location between the highly urbanised East and the more rural regions in the West. The disaster in 2008 was an opportunity not only for rapid urbanisation, but also to plan long-term regional development. Post-disaster tourism is a good example of one sector that emerged. First, the strategy was to trace mainly domestic tourists who were emotionally motivated to contribute to the recovery 


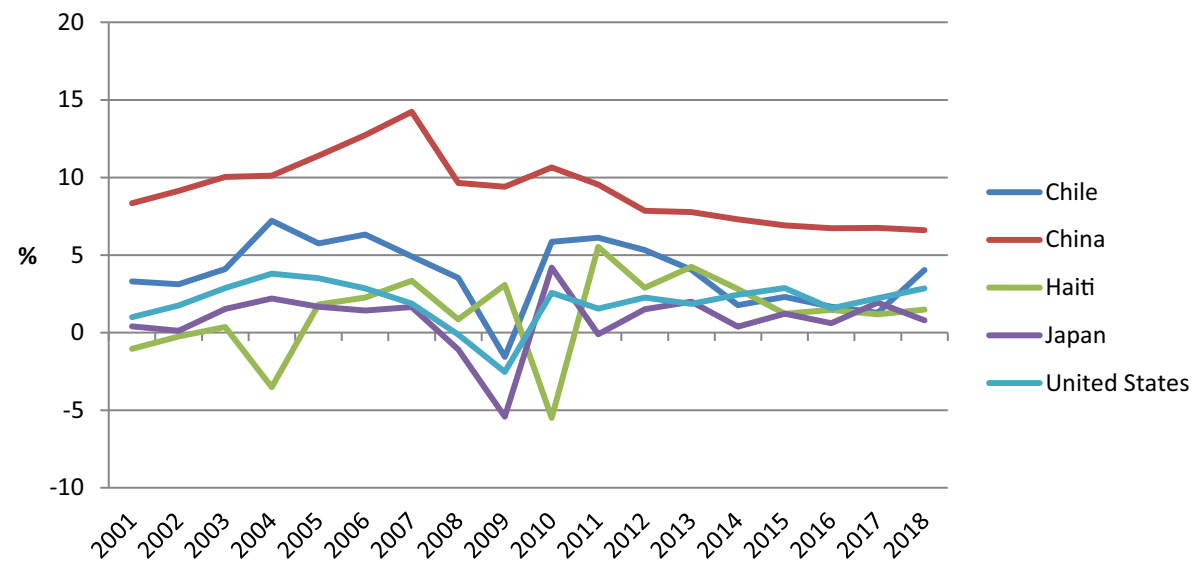

Fig. 9 Annual GDP growth (\%) for the selected countries (Source: Federal Reserve Economic Data, 2019)

in the disaster area, and secondly to bring a large number of tourists both from China and from abroad. In this regard many commercial developers were engaged, the transport system and urban utilities were upgraded and new tourist facilities were put in place. Although, in the case of Sichuan Province, the recovery process was the reconstruction, and was an opportunity for territorial development which also included better organisation, technological upgrading, economic growth, and higher well-being for the population, the governmental approach, focussed on rapid economic recovery, did not necessarily have in view the socio-spatial coherence, multi-stakeholder integration and communication, which is, to a certain extent, a drawback for future sustainability (Guo 2012, Papadopoulos 2016).

In all five cases (see Fig. 9) considered above, one can conclude that the GDP is rather rapidly returning to a positive and rather stable growth rate. One can even notice a temporary boost created by reconstruction spending followed by the rearrangement of the economy on a similar path as before the shock. This sustains the conclusions of Cavallo et al. (2010) who analyse the impact of natural disasters on GDP, combining information from comparative case studies chosen with a synthetic control methodology, and state that, unless a natural disaster triggers political turmoil, it would not affect economic growth (Cavallo et al. 2010). Analysing from another perspective the impact of disasters on the national economy, Albala-Bertrand (1993) concludes that exogenous responses and aid should be immediately directed towards the victims and affected activities, and not towards the economy as a whole, which is resilient anyhow.

These five selected cases reflect five different ways to approach a natural disaster, which demonstrated different resilience approaches and performance in reducing losses, managing the response and recovery, while capitalizing on the "window of opportunity' created by natural disasters at particular geographical scales.

It should be noted that, the overall performance in managing long-term transformations after disasters can be illustrated by complex indicators of quality of life, well-being or development that are more comprehensive than the commonly used 
Table 4 The impact of the selected natural disasters on HDI evolution

\begin{tabular}{|c|c|c|c|c|c|}
\hline \multicolumn{2}{|c|}{ Human Development Index } & \multirow{2}{*}{$\begin{array}{l}5 \text { years before } \\
\text { the disaster } \\
\mathbf{0 . 7 9 5 8}\end{array}$} & \multirow{2}{*}{$\begin{array}{l}5 \text { years after the } \\
\text { disaster } \\
\mathbf{0 . 8 2 6 6}\end{array}$} & \multirow{2}{*}{$\begin{array}{l}\text { Growth } \\
\mathbf{+ 0 . 0 3 0 8}\end{array}$} & \multirow{2}{*}{$\begin{array}{l}\text { Growth rate }(\%) \\
\mathbf{3 . 8 7 0 3}\end{array}$} \\
\hline Chile & All country & & & & \\
\hline & Most affected & 0.7821 & 0.8122 & +0.0310 & 3.8811 \\
\hline & $\begin{array}{l}\text { Not/least } \\
\text { affected }\end{array}$ & 0.7832 & 0.8134 & +0.0303 & 3.8625 \\
\hline \multirow{3}{*}{$\begin{array}{l}\text { China } \\
(2008)\end{array}$} & All country & 0.6484 & 0.7130 & +0.0646 & 9.9630 \\
\hline & Most affected & 0.5980 & 0.6734 & +0.0754 & 12.6087 \\
\hline & $\begin{array}{l}\text { Not/least } \\
\text { affected }\end{array}$ & 0.6535 & 0.7179 & +0.0644 & 9.8476 \\
\hline \multirow{3}{*}{$\begin{array}{l}\text { Haiti } \\
\text { (2010) }\end{array}$} & All country & 0.4620 & 0.4856 & +0.0236 & 5.1082 \\
\hline & Most affected & 0.4537 & 0.4746 & +0.0209 & 4.5989 \\
\hline & $\begin{array}{l}\text { Not/least } \\
\text { affected }\end{array}$ & 0.4310 & 0.4658 & +0.0348 & 8.0826 \\
\hline \multirow{3}{*}{$\begin{array}{l}\text { Japan } \\
(2011)\end{array}$} & All country & 0.8798 & 0.9018 & +0.0220 & 2.5006 \\
\hline & Most affected & 0.8482 & 0.8728 & +0.0246 & 2.9003 \\
\hline & $\begin{array}{l}\text { Not/least } \\
\text { affected }\end{array}$ & 0.8730 & 0.8948 & +0.0218 & 2.4945 \\
\hline \multirow{3}{*}{$\begin{array}{l}\text { USA } \\
(2005)\end{array}$} & All country & 0.8896 & 0.9110 & +0.0214 & 2.4056 \\
\hline & Most affected & 0.8586 & 0.8790 & +0.0204 & 2.3760 \\
\hline & $\begin{array}{l}\text { Not/least } \\
\text { affected }\end{array}$ & 0.8872 & 0.9075 & +0.0203 & 2.2895 \\
\hline
\end{tabular}

GDP. For illustration, we have chosen the Human Development Index (HDI) which is a well-known composite index which measures average achievement in three basic dimensions of human development - a long and healthy life (reflected by life expectancy), knowledge (by expected and mean years of schooling), and a decent standard of living (GNI index). HDI can be calculated not just at the national level, but also at smaller scales (see the subnational HDI). It is more suited to study the implications of a natural disaster on societal transformation. Human development is affected by high intensity natural shocks that take lives, causes injuries/disabilities, and destroy the physical and socio-economic assets. The effects on vulnerable territories also consist of reducing the available quantity of food, impeding access to education, and health facilities, and reducing incomes (Padli et al. 2018; Crespo Cuaresma 2010) (Table 4).

The HDI appears to register a general growth in all cases - in both exposed and not exposed areas. More important, the affected areas grew more compared with the rest of the national territory in China, USA and Japan which all had strong economies and important available capacity. This means that they used the window of opportunity not just for short-term response and recovery after the shock, but also to upgrade and develop the affected area in order to increase its life quality/ habitability. This does not mean that the three countries had a similar approach; for example, in the USA, state intervention was sustained to a great extent by insurance indemnities that covered almost $40 \%$ of the reconstruction expenses after Hurricane Katrina. In contrast, in China, the reconstruction after the Sichuan Earthquake was 
completed in less than 3 years by using virtually exclusively the support of central and local government (Shi and Kasperson 2015). At present, only in the case of Haiti do the affected areas have much lower values of HD, than the other regions of the country, which suggests that the whole disaster recovery process was mismanaged, while the opportunity for development was not taken.

\section{Conclusions}

Disasters open up opportunities to rebuild and improve outcomes ('blessings in disguise'), including mitigating future disasters. They provide valuable learning experience how to cope with extreme stress. Disasters provide outside economic stimulus to the affected economy through insurance and through private and public sector assistance (Rose 2014). The concept of resilience is useful in putting disasters in a new perspective, if a broader approach is taken, i.e. transitioning from passive resilience (just response and recovery) to transformational resilience (through adaptation and systemic changes). In this sense, the crisis is also a time of unexpected and more diversified interactions that take place between previously separated elements of the territorial systems that is able to give birth to new unpredicted foci for future development.

In order to capitalise on the 'window of opportunity' opened by turbulence and incertainty, disasters should be addressed differently by taking into account the specificities of each territory and the proper scale of analysis. Therefore, different scales should be considered and different indicators should be selected in order to assess the overall long-term impact of natural shocks that require different types of intervention and planning policies. GDP and the national scale are not always suitable to be used as indices - not even in cross-country international evaluations. They do not reflect the real impact of the shock, nor the transformational processes that arise.

As a consequence, more complex indicators such as the HDI might provide a more comprehensive perspective on the evolution of a territory after the disaster. It can be stated that vulnerability to natural disasters is higher in countries or regions that have a low HDI, but it is not conclusive that natural shocks reduce human development, some at least in recent times, the external support (national and international support and aid) compensate for short-term losses, while the economy makes its own adjustments in the medium and long-term. In four of the five case studies, the HDI actually appeared to increase more in the affected areas than in the regions that were not affected. The exception is Haiti, as a result of the inappropriate management of funds and investments during the recovery process and the spatial inadequacy of the measures.

In the aftermath of increasingly intense and frequent disasters that are faced by all types of territories, one should reflect on an emerging dilemma. Is it really better not to have losses and to conserve the territorial system as such and not to have to make radical changes like those induced by destructive natural disasters? If not, after finding ways to tackle all natural hazards at all scales, society can learn to understand the role of disasters as a means to promote novelty, to radically change 
the systems, when they do not function, and to transform society and assets in order to respond better and more sustainably to current trends and needs. The 'blessings in disguise' premise will certainly need more substantive research.

Funding This work was supported by a grant of Ministry of Research and Innovation, CNCS-UEFISCDI, project number PN-III-P4-ID-PCCF-2016-0166, within PNCDI III project 'ReGrowEU-Advancing ground-breaking research in regional growth and development theories, through a resilience approach: towards a convergent, balanced and sustainable European Union'.

Funding Open access funding provided by Open University of The Netherlands.

Open Access This article is licensed under a Creative Commons Attribution 4.0 International License, which permits use, sharing, adaptation, distribution and reproduction in any medium or format, as long as you give appropriate credit to the original author(s) and the source, provide a link to the Creative Commons licence, and indicate if changes were made. The images or other third party material in this article are included in the article's Creative Commons licence, unless indicated otherwise in a credit line to the material. If material is not included in the article's Creative Commons licence and your intended use is not permitted by statutory regulation or exceeds the permitted use, you will need to obtain permission directly from the copyright holder. To view a copy of this licence, visit http://creativecommons.org/licenses/by/4.0/.

\section{References}

Adger WN (2006) Vulnerability. Glob Environ Chang 16(3):268-281

Albala-Bertrand JM (1993) Natural disaster situations and growth: a macroeconomic model for sudden disaster impacts. World Dev 21(9):1417-1434. https://doi.org/10.1016/0305-750X(93)90122-P

Albala-Bertrand JM (2007) Globalization and localization: an economic approach. In: Rodríguez H, Quarantelli EL, Rowe Dynes R (eds) Handbook of disaster research. Handbooks of sociology and social research. Springer, New York

Allen CR, Angeler DG, Cumming GS, Folke C, Twidwell D, Uden DR (2016) Quantifying spatial resilience. J Appl Ecol 53(3):625-635. https://doi.org/10.1111/1365-2664.12634

Beck U (1992) Risk society-towards a new modernity. SAGE, London

Béné C (2018) Concept note: measuring resilience across and between scales and how to do it. Produced by TANGO International as part of the Resilience Evaluation, Analysis and Learning (REAL) Associate Award, https://www.fsnnetwork.org/sites/default/files/ConceptNote_MultiscaleResilience_ FINAL_508_0.pdf

Berke PR, Campanella TJ (2006) Planning for postdisaster resiliency. Ann Am Acad Pol Soc Sci 604(1):192-207. https://doi.org/10.1177/0002716205285533

Biggs R, Schlüter M, Biggs D, Bohensky EL, BurnSilver S, Cundill G, Dakos V, Daw TM, Evans LS, Kotschy K, Leitch AM, Meek C, Quinlan A, Raudsepp-Hearne C, Robards MD, Schoon ML, Schultz L, West PC (2012) Toward principles for enhancing the resilience of ecosystem services. Annu Rev Environ Resour 37(1):421-448. https://doi.org/10.1146/annurev-environ-051211-123836

Biggs R, Peterson GD, Rocha JC (2018) The regime shifts database: a framework for analyzing regime shifts in social-ecological systems. Ecol Soc 23(3):9. https://doi.org/10.5751/ES-10264-230309

Biquet J-M (2013) Haiti: between emergency and reconstruction: an inadequate response. Revue Int Polit Devel. https://doi.org/10.4000/poldev.1600

Borsekova K, Nijkamp P (eds) (2019) Resilience and urban disasters: surviving cities. Edward Elgar Publishing, Cheltenham

Borsekova K, Nijkamp P, Guevara P (2018) Urban resilience patterns after an external shock: an exploratory study. Int J Disast Risk Re 31:381-392. https://doi.org/10.1016/j.ijdrr.2018.05.012

Botzen WJW, Deschenes O, Sanders M (2019) The economic impacts of natural disasters: a review of models and empirical studies. Rev Environ Econ Policy 13(2):167-188. https://doi.org/10.1093/reep/ rez004

Bristow G, Healy A (2017) Innovation and regional economic resilience: an exploratory analysis. Ann Reg Sci 60(2):265-284. https://doi.org/10.1007/s00168-017-0841-6

de Bruijn K, Buurman J, Mens M, Dahm R, Klijn F (2017) Resilience in practice : five principles to enable societies to cope with extreme weather events. Environ Sci Policy 70:21-30. https://doi.org/10.1016/ j.envsci.2017.02.001 
Bujones A, Jaskiewicz K, Linakis L, McGirr M (2013) A framework for analyzing resilience in fragile and conflict-affected situations. USAID Final Report. Columbia University, https://sipa.columbia. edu/file/3247/download?token=cjPWfv7A

Burby RJ (2006) Hurricane Katrina and the paradoxes of government disaster policy: bringing about wise governmental decisions for hazardous areas. Ann Am Acad Pol Soc Sci 604(1):171-191. https://doi. org/10.1177/0002716205284676

Cavallo E, Galiani S, Noy I, Pantano J (2010) Catastrophic natural disasters and economic growth. IDB working paper series, no. IDBWP, 183. Inter-American Development Bank (IDB), Washington, DC

Chhibber A, Laajaj R (2008) Natural disasters and economic development impact, response and preparedness. J Afr Econ 17:7-49

Chhibber A, Laajaj R (2011) Securing against natural disasters: better preparedness and better development, chapter 8. In: Marratos G (ed) Security and development. Edward Elgar Publishing, Cheltenham

Contreras D, Blaschke T, Hodgson ME (2016) Lack of spatial resilience in a recovery process: Case L'Aquila, Italy. Technol Forecast Soc Change. https://doi.org/10.1016/j.techfore.2016.12.010

Crespo Cuaresma J (2010) Natural disasters and human capital accumulation. World Bank Econ Rev 24:280-302

Crespo Cuaresma J, Hlouskova J, Obersteiner M (2008) Natural disasters as creative destruction? Evidence from developing countries. Econ Inq 46(2):214-226. https://doi.org/10.1111/j.1465-7295. 2007.00063.x

Cutter SL, Derakhshan S (2018) Temporal and spatial change in disaster resilience in US counties, 2010-2015. Environ Hazards. https://doi.org/10.1080/17477891.2018.1511405

Doucouliagos H, Paldam M (2007) Aid effectiveness on growth: a meta study. Eur J Polit Econ 24:1-24

EPA (Environmental Protection Agency) (2015) Environmental resilience: exploring scientific concepts for strengthening community resilience to disasters. EPA/600/R-15/163, 2015. U.S. Environmental Protection Agency, Washington, DC

Fiksel J (2003) Designing resilient, sustainable systems. Environ Sci Technol 37(23):5330-5339. https:// doi.org/10.1021/es0344819

Flowers B (2018) The economics of natural disasters, page one economics newsletter. Federal Reserve Bank of St. Louis, St. Louis, pp 1-9

Folke C (2006) Resilience: the emergence of a perspective for social-ecological systems analyses. Glob Environ Chang 16(3):253-267. https://doi.org/10.1016/j.gloenvcha

Gall M, Borden KA, Cutter SL (2009) When do losses count?: six fallacies of natural hazards loss data. B Am Meteorol Soc 90(6):799-810. https://doi.org/10.1175/2008BAMS2721.1

Gassebner M, Keck A, Teh R (2010) Shaken, not stirred: the impact of disasters on international trade. Rev Int Econ 18:351-368

Gharajedaghi J (2006) Systems thinking: managing chaos and complexity: a platform for designing business architecture, 2nd edn. Elsevier, Amsterdam

Guo Y (2012) Urban resilience in post-disaster reconstruction: towards a resilient development in Sichuan, China. Int J Disast Risk Sc 3(1):45-55. https://doi.org/10.1007/s13753-012-0006-2

Hallegatte S (2014) Natural disasters and climate change an economic perspective. Springer, Berlin Heidelberg https://doi.org/10.1007/978-3-319-08933-1

Hayashi T (2012) Japan's post-disaster economic reconstruction: from Kobe to Tohoku: Japan's post-disaster reconstruction. Asian Econ J 26(3):189-210. https://doi.org/10.1111/j.1467-8381.2012.02082. $\mathrm{X}$

IRP (2013) The great east Japan earthquake 2011 — case studies, international recovery platform, march 2013

Izumi T, Shaw R, Djalante R, Ishiwatari M, Komino T (2019) Disaster risk reduction and innovations. Prog Disaster Sci 2:100033. https://doi.org/10.1016/j.pdisas.2019.100033

Kahn ME (2005) The death toll from natural disasters: the role of income, geography, and institutions. Rev Econ Stat 87:271-284

Klomp J (2016) Economic development and natural disasters: a satellite data analysis. Glob Environ Chang 36:67-88. https://doi.org/10.1016/j.gloenvcha.2015.11.001

Koks EE, Thissen M (2016) A multiregional impact assessment model for disaster analysis. Econ Syst Res 28(4):429-449. https://doi.org/10.1080/09535314.2016.1232701

Likens GE, Franklin JF, Muntz R (2009) Opportunity in the wake of natural "disasters". Science 324(5926):463-463. https://doi.org/10.1126/science.324_463b

Lindell MK (2013) Recovery and reconstruction after disaster. In: Bobrowsky PT (ed) Encyclopedia of natural hazards, pp 812-824 https://doi.org/10.1007/978-1-4020-4399-4_285 
Loayza N, Olaberría E, Rigolini J, Christiaensen L (2009) Natural disasters and medium-term economic growth: the contrasting effects of different events on disaggregated output. Mimeo, The World Bank

Manyena SB, O'Brien G, O'Keefe P, Rose J (2011) Disaster resilience: a bounce back or bounce forward ability? Local Environ Int J Justice Sustain 16(5):417-424. https://doi.org/10.1080/13549839.2011. 583049

McDermott TKJ (2012) The effects of natural disasters on human capital accumulation. Institute for International Integration Studies, Research article, Trinity College, Dublin

MINVU (2011) Ministry of housing and urban development reconstruction plan. ISBN 9789567674534 (First English Edition May 2011)

Modica M, Reggiani A (2014) Spatial economic resilience: overview and perspectives. Netw Spat Econ 15:211. https://doi.org/10.1007/s11067-014-9261-7

Modica M, Zoboli R (2016) Vulnerability, resilience, hazard, risk, damage, and loss: a socio-ecological framework for natural disaster analysis. Web Ecol 16(1):59-62. https://doi.org/10.5194/we-16-592016

Moreno J, Shaw D (2016) Community resilience to power outages after disaster: a case study of the 2010 Chile earthquake and tsunami. Int J Disast Risk Re. https://doi.org/10.1016/j.ijdrr.2018.12.016

Neumayer E, Barthel F (2011) Normalizing economic loss from natural disasters: a global analysis. Glob Environ Chang 21(1):13-24. https://doi.org/10.1016/j.gloenvcha.2010.10.004

Nijkamp P, Ratajczak W (2013) The Spatial Economy-a Holistic Perspective (Research Memorandum; No. 2013-37). Faculty of Economics and Business Administration, Amsterdam

Noy I (2009) The macroeconomic consequences of disasters. J Dev Econ 88(2):221-231

Noy I, Yonson R (2018) Economic vulnerability and resilience to natural hazards: a survey of concepts and measurements. Sustainability 10(8):2850. https://doi.org/10.3390/su10082850

Okuyama Y, Hewings GJ, Sonis M (2004) Modeling spatial and economic impacts of disasters. Springer, Berlin Heidelberg, pp 77-101 https://doi.org/10.1007/978-3-540-24787-6_5

Padli J, Habibullah MS, Baharom AH (2018) The impact of human development on natural disaster fatalities and damage: panel data evidence. Econ Res Ekon Istraživanja 31(1):1557-1573. https://doi.org/ 10.1080/1331677X.2018.1504689

Papadopoulos A (2016) Resilience: the ultimate sustainability: lessons from failing to develop a stronger and safer built environment, 2nd edn. Resilience Action Fund

Platt S (2019) Planning recovery and reconstruction after the 2010 Maule earthquake and tsunami in Chile. In: Brunetta G, Caldarice O, Tollin N, Rosas-Casals M, Morató J (eds) Urban resilience for risk and adaptation governance, pp 285-304 https://doi.org/10.1007/978-3-319-76944-8_16

Platt S, So E (2016) Speed or deliberation-a comparison of post disaster recovery in Japan, Turkey and Chile. Disasters. https://doi.org/10.1111/disa.12219

Pudelko F, Hundt C, Holtermann L (2018) Gauging two sides of regional economic resilience in Western Germany-why sensitivity and recovery should not be lumped together. Rev Reg Res 38:141. https:// doi.org/10.1007/s10037-018-0124-4

Reggiani A, De Graaff T, Nijkamp P (2002) Resilience: an evolutionary approach to spatial economic systems. Netw Spat Econ 2:211. https://doi.org/10.1023/A:1015377515690

Rehdanz K, Welsch H, Narita D, Okubo T (2015) Well-being effects of a major natural disaster: the case of Fukushima. J Econ Behav Organ 116:500-517. https://doi.org/10.1016/j.jebo.2015.05.014

Rose A (2014) Economic resilience and its contribution to the sustainability of cities. In: Gasparini P, Manfredi G, Asprone D (eds) Resilience and Sustainability in relation to natural disasters: a challenge for future cities https://doi.org/10.1007/978-3-319-04316-6

Rusche K (2010) Quality of life in the regions: an exploratory spatial data analysis for west German labor markets. Jahrb Reg wiss 30(1):1-22. https://doi.org/10.1007/s10037-009-0042-6

Sawada Y, Takasaki Y (2017) Natural disaster, poverty, and development: an introduction. World Dev 94:2-15. https://doi.org/10.1016/j.worlddev.2016.12.035

Scoppetta C (2016) Natural' disasters as (neo-liberal) opportunity? Discussing post-hurricane Katrina urban regeneration in New Orleans. Tema J Land Use Mobil Environ. https://doi.org/10.6092/1970$9870 / 3725$

Shabnam N (2014) Natural disasters and economic growth: a review. Int J Disast Risk Sci 5(2):157-163. https://doi.org/10.1007/s13753-014-0022-5

Shi P, Kasperson R (eds) (2015) World atlas of natural disaster risk. Springer, New York https://doi.org/10. 1007/978-3-662-45430-5

Siembieda W, Johnson L, Franco G (2012) Rebuild fast but rebuild better: Chile's initial recovery following the 27 february 2010 earthquake and tsunami. Earthq Spectra 28(S1):S621-S641. https://doi.org/10. $1193 / 1.4000025$ 
Skidmore M, Toya H (2002) Do natural disasters promote long-run growth? Econ Inq 40(4):664-687. https://doi.org/10.1093/ei/40.4.664

Smit B, Wandel J (2006) Adaptation, adaptive capacity and vulnerability. Glob Environ Chang 16:282-292. https://doi.org/10.1016/j.gloenvcha.2006.03.008

Sudmeier-Rieux K (2014) Resilience - an emerging paradigm of danger or of hope? Disaster Prev Manag 23(1):67-80

Taleb NN (2012) Antifragile: things that gain from disorder. Random House, New York

Thomalla F, Boyland M, Johnson K, Ensor J, Tuhkanen H, Gerger Swartling Å, Han G, Forrester J, Wahl D (2018) Transforming development and disaster risk. Sustainability 10(5):1458. https://doi. org/10.3390/su 10051458

Hideki Toya H, Skidmore M (2007) Economic development and the impacts of natural disasters. Economics Letters 94(1):20-25. https://doi.org/10.1177/1091142113510198

UN (United Nations) (2016) Report of the open-ended intergovernmental expert working group on indicators and terminology relating to disaster risk reduction. Seventy-first Session, Agenda Item 19 (c) Sustainable Development: Disaster Risk Reduction.

UNISDR (United Nations Office for Disaster Risk Reduction) (2015) Sendai framework for disaster risk reduction 2015-2030. http://www.wcdrr.org/uploads/Sendai_Framework for Disaster Risk Reduction 2015-2030.pdf. Accessed 15 Sept 2019

Vale L, Campanella TJ (2005) The resilient city: how modern cities recover from disaster. Oxford University Press, Oxford

Walker BH, Carpenter SR, Rockstrom J, Crepin AS, Peterson GD (2012) Drivers, "slow" variables, "fast" variables, shocks, and resilience. Ecol Soc 17(3):30

WB (World Bank) (2019) Rebuilding Haitian infrastructure and institutions, results briefs, May 3, 2019. https://www.worldbank.org/en/results/2019/05/03/rebuilding-haitian-infrastructure-and-institutions. Accessed 15 Sept 2019

WBG (World Bank Group) (2017) Crisis response and resilience to systemic shocks. Lessons from IEG Evaluations

Yamamura E (2013) The impact of natural disasters on income inequality: analysis using panel data during the period 1970 to 2004. International Economic Journal 29(3):359-374. https://doi.org/10.1080/ 10168737.2015 .1020323

Yigitcanlar T, Inkinen T (2019) Geographics of disruption. Springer, Berlin

Zeeman EC (1976) Catastrophe theory. Sci Am 234(4):65-83

Zseleczky L, Yosef S (2014) Are shocks really increasing? A selective review of the global frequency, severity, scope and impact of five types of. IFPRI, Washington, D.C, May 2014. 2020 conference paper 5

Publisher's Note Springer Nature remains neutral with regard to jurisdictional claims in published maps and institutional affiliations. 